\title{
DE TOEKOMST VAN VERSCHILLENDE CULTURES IN SURINAME.
}

\author{
DOOR
}

\section{TJ. PYTTERSEN.}

\section{Suiker.}

(Slot.)

\section{Rietziekten.}

Sedert omstreeks 1885 is door het optreden der serehziekte op Java een groote ommekeer in de suikercultuur aldaar ingetreden. Wetenschappelijke hulp werd noodig geacht en thans is deze op het gebied èn van cultuur èn van suikerwinning van dien aard, dat zij herhaaldelijk als voorbeeld wordt aangehaald.

Hoewel de zaadrietsoortwinning zeker op succes kan wijzen, is het tot heden niet gelukt de kostbare bibit (plantstek)-voorziening uit de bergen te kunnen uitschakelen, en, tenzij dit binnen afzienbaren tijd mogelijk wordt, kan worden aangenomen, dat de kosten aan plantmateriaal op Java vrij hoog zullen blijven, in alle gevallen veel hooger dan op Cuba en ook in Suriname.

In Suriname heeft men geen last van ernstige rietziekten en insectenplagen en kan men snitten aanhouden waardoor niet alleen de rekening van het plantmateriaal laag blijft, maar waardoor tevens de bewerkingskosten van den aanplant belangrijk beneden het Javapeil blijven.

Diephuis zegt:

„De grond langs de kust en rivieren is over het algemeen zeer vruchtbaar en daardoor bemesting onnoodig, belangrijke rietziekten zijn er niet, de bestrijding van eventueel voorkomende insectenplagen (froghopper of boorder) is door bevloeiing zeer gemakkelijk .... Toch geloof ik, dat het in de toekomst mogelijk moet zijn de suikercultuur in Suriname tot een rendeerende cultuur te maken. Grond en klimaat zijn geschikt voor de rietcultuur, de grond is goedkoop, bemesting schijnt bij rationeele cultuur d.i. op tijd braken of wisselcultuur niet noodig, het transport dat te water geschiedt is niet duur." 
Een voorname plaats zal in den proef-cultuurtuin dienen in te nemen het winnen van superieure zaadrietsoorten, zooals reeds jaren op Java en ook in Britsch-West-Indië wordt getracht en gedaan.

Goede grondbewerking en een verzorgd onderhoud van den aanplant zal in Suriname ongetwijfeld een gunstig resultaat hebben, zal de productie gemakkelijk kunnen opvoeren.

\section{Machines.}

Ik zal hier niet uitvoerig de verschillende machines, welke de suikercultuur kan benutten, bespreken. Reeds vroeger heb ik daar het een en ander van gezegd.

Vaststaat dat machinale grondbewerking mogelijk is en dat sommige grondtypes zware krachtige tractors kunnen dragen waardoor in één tractorgang een reeks ploegscharen kunnen worden getrokken, waardoor tevens veel minder werkkrachten gebonden worden. (Zie mijn artikel ,Nieuwe Wegen" voorkomende in het Julinummer 1920 van de W.-I. Gids.)

De zwaarste tractor in de suikercultuur benut is er een van 125 P.K. op Java.

Het is geen nieuws te wijzen op een goede grondbewerking. Deze was honderd jaar geleden in Suriname reeds zeer slecht en von Sack was degeen die toen op de waarde van het beploegen der gronden wees, naar aanleiding waarvan verschillende bekende planters de zaak uitvoerig behandelden, maar tot de conclusie kwamen dat daarvoor goed ploegvee noodig was, dat in de kolonie ontbrak en moeilijk kon worden gehouden daar de slaven slechte verzorgers waren.

Machinaal eggen en plantvoren trekken is eveneens mogelijk, terwijl het gotenstelsel - op lichteren grond minder uitgebreid dan op vochtig kleiland - eveneens machinaal kan worden aangebracht en onderhouden.

Ik heb reeds in „Nieuwe Wegen” het Queensland plantwagentje besproken, dat eenige overeenkomst vertoont met den aardappelpooter in Amerika; planten met zeer weinig handenarbeid is daardoor mogelijk geworden.

Wat nu het onderhoud - schoonhouden en aanaarden - van het riet betreft, wijs ik op verschillende methodes, welke ook in Demerary worden toegepast, maar eveneens op een nieuw systeem cultivator door de Avery Company in den handel gebracht.

Deze firma schrijft mij dd. 26 Aug. '20:

„We are enclosing herewith two photographs showing the new Avery 
cane cultivator. One photograph shows the detail very nicely and you can get a good idea of the front arch and the two front wheels which work on a pivot. As the two drive wheels work independently of each other, it is possible when reaching the end of the rows to stop one drive wheel and let the other travel ahead which turns the cultivator square around on the idle drive wheel while the two front wheels pivot to proper position. That puts the machine into position to go back on the next rows.

This cultivator is equiped with a six cylinder upright special motor made for the purpose and it has more than sufficient power to drive the machine under practically all conditions. The other photo shows the various attachments that we can furnish with the cultivator. You will see that we provide a furrow opener shown at the extreme right of the picture for furrowing out the trench in which the cane stubs are planted. The cane can be covered by means of the two discs.

.... To the right of the cultivator is an illustration of the barring off plows which permits throwing the dirt away from the cane roots and by reversing the shovels it can be thrown back again. To the right of the barring off plows is the disc cultivating attachment. This disc cultivator cultivates two complete middles. The clearance of the machine is 42 " With these implements you have everything necessary to do the complete cultivation of sugar cane, and while the machine is still new, yet we have no doubt in our mind but that it is going to revolutionize the sugar cane industry."

Ik zal er niet verder bij stilstaan; mogelijkheden worden aangegeven en een onderzoek doet de praktische waarde vaststellen der nieuwe vindingen. Dergelijke onderzoekingen moeten geschieden door of met steun der Regeering in een land waar geen krachtig particulier initiatief aanwezig is en/of de middelen voor dergelijk onderzoek ontbreken.

Snijden van het riet en transportkwesties.

Herhaaldelijk treft men in de vakbladen besprekingen aan over rietsnijmachines. Vaststaat dat er eigenlijk nog geen goed functioneerende machine is op dit gebied, daar anders niet door Hawai, Louisiana en vooral Cuba uit alle werelddeelen rietsnijders zouden worden aangevoerd, zooals ik boven heb aangetoond.

Het vraagstuk van het snijden van riet is in Suriname niet zoo ingewikkeld als op Java, omdat in het eerste land - door het aanhouden van snitten - het riet gewoon bij den grond kan worden afgesneden, waar op Java ook de penwortel moeten worden geoogst. Een machine dus welke in Suriname bij het rietsnijden zal voldoen, zal in de meeste gevallen op Java niet voldoen.

De transportkwestie zal in Suriname gemakkelijk en zonder hooge kosten zijn op te lossen, daar in de meeste gevallen van watertransport kan worden gebruik gemaakt.

$O p$ de vroegere plantagegronden treft men daarvoor speciaal 
gegraven kanalen (trenzen) aan, welke echter niet geschikt zijn voor mechanisch gedreven vaartuigen vanwege het inkalven der kanten.

De trekkracht zal dus op de wal moeten zijn - locomotieven, tractors -

Zijn de rietvelden langs rivieren of kreken gelegen dan vervalt dit bezwaar.

Het watertransport kan aangenomen worden steeds ongeveer even duur te blijven, de enkele arbeider, de hoogere prijs der vaartuigen en eventueel kostbaarder sleepboot (riviertransport kan dikwijls van den stroom profiteeren) drukken betrekkelijk weinig op het vervoer.

Anders is dit op Java,waar men geen watertransport aantreft uitgezonderd hier en daar een onbeteekenend beetje.

Hier voelt men de stijging der materialen enz. direct veel meer, rail, locomotieven, dwarsliggers, steenkolen, werkloonen, e. a.

De suikerfabrieken welke in de toekomst in Suriname hetzij door Nederlanders, hetzij door buitenlanders zullen worden opgericht, zullen aan de rivieren gelegen zijn - tenminste de meeste - waar zij over fabriekswater beschikken en tevens de groote voordeelen van het waterrtransport bezitten. De aanvoer van materialen van-, de afvoer van producten naar de zeeschepen blijft daardoor goedkoop, een kwestie welke zeer ten voordeele van Suriname komt. Dit alleen reeds verschilt met Java gemiddeld ongeveer 25 cent per picol suiker.

De beschikking over eigen aaneengesloten grondcomplexen in Suriname maakt de transportkwestie aldaar zooveel gemakkelijker en goedkooper dan op Java, waar de rietvelden zeer verspreid liggen, zoodat daardoor per vlakteeenheid omgerekend veel kostbare railbaan noodig is.

\section{Werkvolk.}

Vrij vast staat dat gerekend mag worden dat jaarlijks 10.000 Javanen voor Suriname te verkrijgen zijn en tegen loonen welke bij vroeger vergeleken hoog zijn, maar niet meer dan de gulden per dag naderen, waar Cuba en andere landen tot 5 dollar dagloon moeten betalen (inclusief passage der buitenlandsche arbeiders), waar een gewoon dagloon 3 dollars bedraagt.

Zoolang de Surinaamsche ondernemingen de oude methode van werken met vrijwel uitsluitend handenarbeid moeten toepassen, zoolang zij niet beschikken over meer werkkapitaal om de cultuur tot een hoog peil op te voeren, zal steeds op koelieloonen moeten 

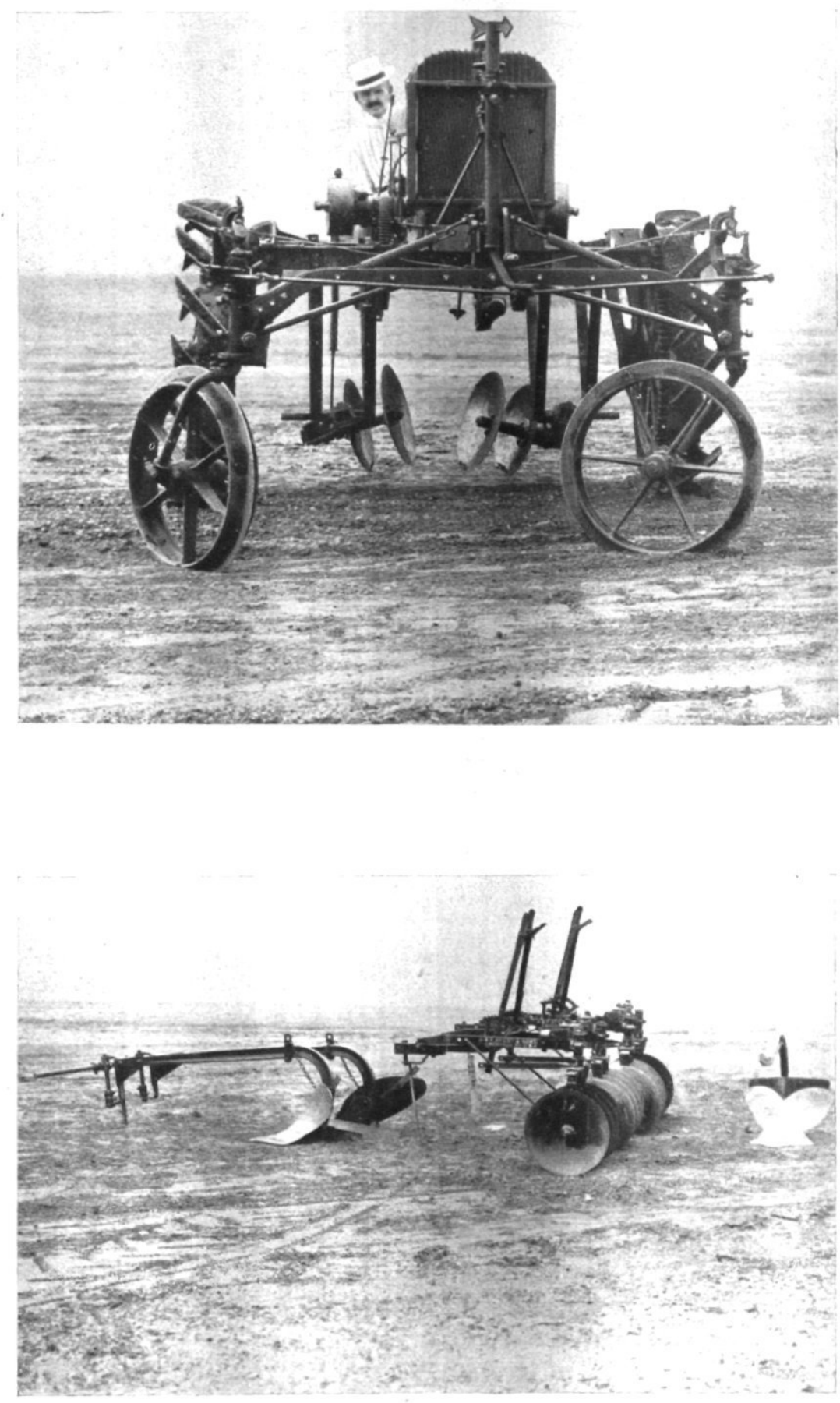

NIEUWE RIET-CULTIVATOR VAN DE AVERY COMP. PEORIA 
gegraven kanalen (trenzen) aan, welke echter niet geschikt zijn voor mechanisch gedreven vaartuigen vanwege het inkalven der kanten.

De trekkracht zal dus op de wal moeten zijn - locomotieven, tractors -

Zijn de rietvelden langs rivieren of kreken gelegen dan vervalt dit bezwaar.

Het watertransport kan aangenomen worden steeds ongeveer even duur te blijven, de enkele arbeider, de hoogere prijs der vaartuigen en eventueel kostbaarder sleepboot (riviertransport kan dikwijls van den stroom profiteeren) drukken betrekkelijk weinig op het vervoer.

Anders is dit op Java,waar men geen watertransport aantreft uitgezonderd hier en daar een onbeteekenend beetje.

Hier voelt men de stijging der materialen enz. direct veel meer, rail, locomotieven, dwarsliggers, steenkolen, werkloonen, e. a.

De suikerfabrieken welke in de toekomst in Suriname hetzij door Nederlanders, hetzij door buitenlanders zullen worden opgericht, zullen aan de rivieren gelegen zijn - tenminste de meeste - waar zij over fabriekswater beschikken en tevens de groote voordeelen van het waterrtransport bezitten. De aanvoer van materialen van-, de afvoer van producten naar de zeeschepen blijft daardoor goedkoop, een kwestie welke zeer ten voordeele van Suriname komt. Dit alleen reeds verschilt met Java gemiddeld ongeveer 25 cent per picol suiker.

De beschikking over eigen aaneengesloten grondcomplexen in Suriname maakt de transportkwestie aldaar zooveel gemakkelijker en goedkooper dan op Java, waar de rietvelden zeer verspreid liggen, zoodat daardoor per vlakteeenheid omgerekend veel kostbare railbaan noodig is.

Werkvolk.

Vrij vast staat dat gerekend mag worden dat jaarlijks 10.000 Javanen voor Suriname te verkrijgen zijn en tegen loonen welke bij vroeger vergeleken hoog zijn, maar niet meer dan de gulden per dag naderen, waar Cuba en andere landen tot 5 dollar dagloon moeten betalen (inclusief passage der buitenlandsche arbeiders), waar een gewoon dagloon 3 dollars bedraagt.

Zoolang de Surinaamsche ondernemingen de oude methode van werken met vrijwel uitsluitend handenarbeid moeten toepassen, zoolang zij niet beschikken over meer werkkapitaal om de cultuur tot een hoog peil op te voeren, zal steeds op koelieloonen moeten 
worden beknibbeld, omdat verhooging dier loonen - ik spreek van gewone tijden - de rentabiliteit der ondernemingen te veel schaadt.

Die methode leidt ten slotte toch tot ondergang.

Suriname kan er slechts dan bovenop komen wanneer bij benutting van gunstige factoren welke het land bezit en bij toepassing van de nieuwste vindingen der suikerindustrie enz. belangrijke voordeelen bij normale markten kunnen worden gecalculeerd; dan ook kan de loonstandaard op een hoog peil worden gebracht.

Een oogenblik van gevoel van verplichting tegenover de natie kan onze finantieele wereld in de beurs doen tasten voor een of ander onderzoek in de kolonie; men kan van die nuchtere wereld niet verwachten dat zij aldaar ondernemingen op touw zet, welke in Oost-Indië met minder kapitaal winstgevender kunnen zijn.

Diephuis zegt in zijn goed doorwerkt verslag:

„Bij terugkeer in New-York bezocht ik de groote suikerfirma Czarnikow-Rionda en deelde een der firmanten mij als zijn zienswijze mede dat de Surinaamsche suiker in de toekomst gemakkelijk plaatsing zal vinden op de New Yorksche markt en wel om de volgende reden.

De suikerproductie in Amerika en Cuba is grooter dan de consumptie, zoodat in de toekomst Amerika zijn geraffineerd zal moeten exporteeren.

Daar bij export van raffinade het betaalde invoerrecht minus I \% gerestitueerd wordt, en het invoerrecht op suiker uit Suriname hooger is dan op suiker uit Cuba, is de restitutie in het eerste geval grooter en zal de raffinadeur daarom gaarne suiker van Suriname koopen.

Stel den suikerprijs in New-York b.v. op 5 d. c. per pond en het invoerrecht voor Cubasuiker zeg I,25 d.c. en voor Surinamesuiker op I,50 d. c. dan zal de fabrikant op Cuba ontvangen 3,75 d. c. en in Suriname 3,50 d.c. Maar in werkelijkheid zal dit verschil geringer zijn, omdat de raffinadeur het invoerrecht op de suiker betaald terug ontvangt minus I \% dus voor Cubasuiker I,25 d. c. minus I \% of 1,2375 d.c. en voor Surinamesuiker I, 50 d. c. minus I \% of 1,4850 d. c. per pond.

Hij kan dus voor Suriname-suiker meer betalen en zal dat doen ook door de concurrentie gedwongen. Het prijsverschil zal dus in de praktijk niet zoo groot zijn als men, afgaande op de invoerrechten, zoude moeten aannemen."

Een op den voorgrond tredend man wees mij op dit door Diephuis genoemde voordeel. Ik kan de groote beteekenis er niet van inzien, het is meegenomen zoolang het duurt, maar wordt het lastig voor de concurrenten dan zullen deze wel zorgen dat het vervalt. In alle gevallen mag het niet als permanent voordeel worden beschouwd.

De werkvolk-kwestie in Suriname is geen punt waarop de ontwikkeling van de kolonie behoeft af te stuiten; zij is niet goedkoop maar goedkooper en minder moeilijk dan, om bij het voornaamste 
land te blijven: Cuba, waar uit China en Europa werkkrachten worden aangevoerd, van welke velen na een bij Suriname vergeleken korte campagne weer huiswaarts keeren, waardoor de loonen zeer hoog moeten blijven.

De beteekenis van het vinden eener goede rietsnijmachine treedt hierdoor naar voren; wordt deze gevonden dan komt het den kostprijs van de Cubaansche suiker ten goede, maar ook de Surinaamsche.

Java met hoogere eischen (uitgraven penwortel) zal daarniet van profiteeren, integendeel, immers verlaging van den Cubaprijs beteekent scherpere concurrentie voor Java.

\section{Terreinen.}

Een eeuw geleden, toen von Sack Suriname bezocht, was de grootste onderneming Visserszorg aan de Beneden-Commewijne gelegen, welke werkte met $230-250$ slaven en in goede jaren 1 millioen ponden suiker produceerde (8000 pic.).

In onzen tijd beteekent dit natuurlijk niets meer, is dit ,kleinbedrijf”, evenals in de naaste toekomst „klein bedrijf” zijn de tegenwoordige Surinaamsche suikerondernemingen en de Javasche uitgezonderd een zeer enkele..

Onze tegenwoordige hulpmiddelen stellen ons in staat zeer uitgestrekte terreincomplexen in één hand te exploiteeren; daardoor slechts zal goedkoop kunnen worden geproduceerd, waardoor aan een scherpe concurrentie het hoofd kan worden geboden.

Suriname biedt voor dergelijke bedrijven de meest gunstige voorwaarden en daarom acht ik de toekomst van het land vaststaand; of die opleving ten slotte door Nederlanders of buitenlanders zal worden bewerkstelligd doet hier minder ter zake, het liefst zou ik zien dat onze landgenooten hier weder hun vierde goede plekje gingen zoeken.

Op Java treffen we een paar fabrieken aan welke per etmaal 2000 ton (32000 pic.) riet of meer kunnen verwerken, waardoor jaarlijks ruim 3 millioen picols riet worden vermalen en tot 350.000 pic. suiker worden geproduceerd.

Een fabriek van een dergelijke capaciteit zal in Suriname jaarlijks ongeveer 6,8 millioen picol riet kunnen verwerken en ruim 700.000 picols suiker winnen.

Daarvoor zullen noodig zijn - een rietproductie aannemend van 1100 pic. per H.A. - ongeveer 6200 H.A. met riet beplant terrein.

Nemen we nu verder gemakshalve aan dat dit riet in 12 maan- 
den rijpt en dat van het totaal cultuuroppervlak $2 / 5$ met riet en $3 / 5$ met wisselbouw gewassen wordt beplant dan is een totaal oppervlak noodig van $15500 \mathrm{H}$.A. en zal de onderneming totaal minstens 17000 H.A. groot moeten zijn.

De kwestie is thans: zijn dergelijke uitgestrekte gunstige terreincomplexen in Suriname te vinden?

De voor een moderne cultuur geschikte terreinen zijn in Suriname in drie hoofdgroepen te verdeelen, nl.:

1. De langs bevaarbaar, zoetwater bevattende, riviergedeelten gelegen lichtere gronden in het bovenland. (Gronden dus welke bij hoogwater niet of bijna nooit worden geïnundeerd.)

2. Reeksen oude polderplantages met verwijdering der bestaande scheidingsdijken en uitgebreid met achterliggend land, terwijl eveneens enorme uitgestrektheden op nieuw in te dijken zeer vruchtbaar terrein in het alluviale gebied te verkrijgen zijn. (Zie mijn rijstartikel.)

3. De Coronievlakte en daarmede overeenkomende grondcomplexen.

Over de eerste gronden het volgende:

Vaststaat:

dat langs de rivieren en kreken in het hooger gelegen land, d. i. het land dat bij hoog water niet onderloopt, vruchtbare lichte cultuurgronden voorkomen,

dat voor zoover deze gronden langs bevaarbaar, zoetwater bevattende riviergedeelten gelegen zijn, zij èn voor transport èn voor bevloeiing gunstige voorwaarden bieden,

dat het suikerrendement op die gronden steeds hoog is geweest, zoodat eertijds bij een laagstaande cultuurmethode en suikerwinning toch nog 4-8 oxhoofden van 1000 Amst. ponden werden per akker verkregen, 53-106 pic. per bouw,

dat door bevloeiing en wisselcultuur de vruchtbaarheid dezer gronden op peil kan worden gehouden,

dat in het algemeen, indien wordt zorggedragen voor een goede grondbewerking en onderhoud van den aanplant, voor het planten van superieure rietsoorten, voor bevloeiing der rietvelden in den drogen tijd, voor het snijden van rijp - en het steeds vermalen van versch gesneden riet, voor het - indien noodig bemesten van den opslag, gunstige resultaten zullen worden verkregen, indien eveneens gezorgd wordt voor een modern ingerichte fabriek en suikerwinning.

Hoeveel bedraagt voor een dergelijke fabriek de kostprijs van 
den picol riet aan den molen? Een normaal suikergehalte aannemende, is dit feitelijk de vraag waar het om gaat. De overige kosten loopen over de wereld niet zooveel uiteen, uitgezonderd de suikerafvoerkosten, welke weder juist in ons geval zeer laag zijn, daar gebruik kan worden gemaakt van watertransport.

Ik neem aan dat op dit terrein, wanneer $2 / 5$ van het totaal cultuuroppervlak jaarlijks met riet beplant wordt en de resteerende $3 / 5$ met wisselbouwgewassen, de vruchtbaarheid der gronden op peil kan worden gehouden, vooral, zooals ik straks reeds zeide, sawahrijst hieronder een voorname rol speelt, dat de wisselbouw slechts zooveel winst oplevert dat zij de kosten van de ontginning - max. $f 400$, - per H.A. - kan goedmaken, dat na riet slechts één snit wordt aangehouden, welke met $2 \frac{1}{2}$ pic. zwavelzure ammonia per H.A. bemest wordt en dat ten slotte dan gerekend mag worden op een gemiddeld rietproduct van 1200 pic. per H.A. overeenkomende met ongeveer 850 pic. per bouw.

\section{Grondhuur.}

De jaarlijksche vergoeding van het ingebruik nemen der gronden aan het Gouvernement bedraagt zoo weinig dat deze praktisch niet drukt op de kosten van een picol riet aan den molen.

\section{Grondbewerking en onderhoud.}

Op Java rekende men een paar jaar geleden voor het mechanisch diep ploegen van vrij zwaren grond zonder afschrijving en chauffeurskosten, $f 7$,- per bouw, in Demerary volgens het Studie Rapport $f 3,-$ per akker.

De Heer Smits rekent voor Californië bij den rijstbouw ongeveer $f 35$,- per H.A. - alle uitgaven tot bevloeiing -, terwijl hij voor Indië aanneemt bij gebruik van Clevelandtractors $f$ 90,per H.A. in welken prijs het volgende begrepen is:

Ploegwerk November - Disken December - Zaaien — Maaien - Vervoer - Dorschen en Vervoer - Disken Juni - Ploegen Juli-Aug. - Disken Sept.-Oct. - Afschrijving, Reparatie en Brandstof enz. - Inlandsch en Europeesch Personeel -

Wanneer wij nu voor ploegen, eggen en plantgeulen trekken ,met afschrijving enz. aannemen $f 50$,- per H.A. voor de Surinaamsche lichtere gronden komt mij dit ongeveer juist voor.

Voor een gotenstelsel op die gronden neem ik $f$ 10,- per H.A. aan.

Een dergelijk gotenstelsel behoeft hier niet zoo intens te zijn 
als op zware vochtige klei en staat daardoor tevens een machinaal bewerken der gronden minder in den weg.

Voor planten met gebruikmaking van het reeds vroeger door mij genoemde Queensland plantwagentje reken ik $f 5$,- per H.A., voor bibit(plantstek) $f 35$,- per zelfde oppervlak.

Voor onderhoud en bewerkingen $5 \times f 10$, - totaal $f 50$, -

Snij- en transportloon 12 cent per picol (afschrijving en onderhoud der noodige vervoermiddelen enz. inbegrepen), voor toezicht incl. ${ }^{1 / 2}$ salaris administrateur, $f 28$,- per H.A., voor irrigatie één cent per picol riet.

We krijgen dan voor één H.A. nieuwen aanplant, bij een productie van 1300 picols riet per H.A.:

Ploegen, eggen, geulentrekken . . . . . . . . f 50,Goten . . . . . . . . . . . . . . . . 10,-

Planten . . . . . . . . . . . . . . . . . . . . . - 5,-

Onderhoud. . . . . . . . . . . . . . . . 50,-

Bibit . . . . . . . . . . . . . . - 35,-

Snij- en transportkosten . . . . . . . . . . . . 156,-

Toezicht . . . . . . . . . . . . . . . . . 28,-

Irrigatie . . . . . . . . . . . . . . . . . . - 13,-

Totaal per 1300 pic. . . . . 7347,

Voor de snit bedragen de kosten (1100 pic. riet per H.A.): Geulen ophalen . . . . . . . . . . . . . . . $f$ 25,Goten ophalen . . . . . . . . . . . . . . . . - 5,4 bewerkingen . . . . . . . . . . . . . . . . . . - 40,Bibit (Bijplanten) . . . . . . . . . . . . . . . . 5,$2^{1} / 2$ Pic. Zwav. Ammonia met inbrengen . . . . . . - 75,Snij- en transportkosten . . . . . . . . . . . - 132,Toezicht . . . . . . . . . . . . . . . . . 28,Irrigatie. . . . . . . . . . . . . . . . . . . . - 11,Totaal. . . . $321,-$

Op 2400 picols riet drukken deze kosten dus met $f 347$,- plus $f 321$, - of totaal $f 668$, - of per picol 27,8 cent, rond 28 cent.

Een suikerrendement aannemende van $10 \%$, hetgeen voor die gronden zeer zeker verre beneden het gemiddelde moet zijn, komt de picol suiker tot den molen op $f 2,80$ of per ton op ruim $f 45$,- .

Welk een perspectief wordt hier de rietsuikerwereld geopend.

Men kan mij tegenwerpen dat ik de cijfers te gunstig heb opge- 
zet; ik meen van niet, maar ik geef gaarne toe, dat die mogelijkheid bestaat, maar die kostprijs kan een belangrijke stijging verdragen eer hij die in andere landen nabij komt.

Noodig is dat de juistheid ervan wordt nagegaan èn in een proef-cultuurtuin èn op het terrein zelf door particulieren.

Ik heb in mijn rijstartikel gewezen op de groote voordeelen, welke de rijstbouw voor de suikercultuur bevat, dat daardoor mogelijk wordt de proeven te nemen zonder belangrijke risico, temeer indien het product kan worden verwerkt door de bestaande Surinaamsche fabrieken.

Ik wil nog even blijven stilstaan bij de kwestie hoe ik mij een dergelijke onderneming denk.

In een meer uitgebreid voorstel schreef ik indertijd ongeveer het volgende:

Ik stel me een suikeronderneming voor langs de Surinamerivier of een harer zijtakken gelegen, waardoor een verbinding over water mogelijk is met de zeeschepen en het bevolkingscentrum.

In de eerste jaren acht ik een dergelijke ligging te verkiezen boven die aan een der andere rivieren, omdat men daar veel te geïsoleerd is en de opzet daardoor bemoeilijkt wordt en onnoodig veel geld verslindt.

De fabriek wordt gebouwd langs den oever in het beneden deel der onderneming, zoodat het ruwproduct (riet) geladen op vaartuigen door de kracht van den stroom naar den molen wordt getransporteerd.

De aanplant wordt verdeeld in 10 blokken elk van $1400 \mathrm{H}$.A. bestaande uit 280 H.A. nieuwen aanplant, 280 H.A. snit en verder uit wisselcultures.

Een riettuin is dus groot $280 \mathrm{H}$.A. netto; de breedte langs den oever bedraagt 1 K.M., de diepte 2,8 K.M.

Elk blok beschikt over een steiger, waar langs de rietponten komen en het middels lorries aangevoerde riet opnemen.

Een dergelijk blok heeft zijn eigen machines en railmateriaal, heeft zijn eigen vaste arbeiders en staat onder toezicht van een blokopzichter met eenige toegevoegde hulpopzichters.

Het snijloon heb ik opgezet op 7 cent per picol, en aangenomen, dat een arbeider(ster) per dag minstens 20 picol (niet uitgegraven) zal snijden, zoodat goed geld kan worden verdiend; het transport van het riet naar den steiger incl. alle kosten en afschrijvingen is aangenomen op 3 cent per picol riet, het vervoer incl. afschrijving op de vaartuigen en sleepbooten op 2 cent p. p.

Elk blok neemt minstens 5 K.M. rivieroever in beslag, de totale 
onderneming dus 50 K.M. netto of bruto zeer zeker 55 K.M.; worden beide oevers tegelijk gebruikt dan wordt dus ongeveer 28 K.M. rivier in beslag genomen.

Deze lengte is kleiner dan de afstand tusschen de verste riettuinen op enkele groote Javaondernemingen.

Wat de onder 2. genoemde terreinen betreft, heb ik deze reeds eenigszins uitvoerig beschreven in mijn rijstartikel.

Reeksen oude plantages uitgebreid met achter liggend land, zullen groote, gedeeltelijk door dijken omsloten complexen vormen, waarin de groot-cultuur zich zal kunnen ontwikkelen.

Wordt geregeld gezorgd dat het grondwaterpeil niet te hoog komt, dan zal de landbouwtechniek op deze terreinen beter kunnen worden aangewend dan thans het geval is; de bewerkingskosten zullen hier hooger zijn, dan op de lichte gronden, waar tegenover staat dat na een nieuwen aanplant twee snitten instede van één kunnen worden aangehouden, welke wellicht geen, anders zéér weinig bemesting vereischen.

De rietproductie zal grooter zijn, het suikerrendement lager.

Groote geschikte terreinen zijn naast het Surinameriviergebied te vinden langs de Saramacca- en Coppenamerivier, maar ook elders. Het vormen van groote complexen in streken waar oude plantages voorkomen brengt verschillende bezwaren mede.

Het Studie-Rapport zegt:

„Verlaten plantages, Van de honderden plantages die aangelegd zijn, werken er thans nog 75 al heeft het bedrijf soms weinig te beteekenen.

De overige liggen onbeheerd en verlaten. Mocht een opleving van Suriname aanleiding geven tot heropening dezer ondernemingen, dan zal men den nieuwen eigenaar moeten vrijwaren tegen aanspraken van vroegere bezitters. Het mag zijn dat van vele plantages geen eigenaren meer in leven zijn, dus van het laten gelden van rechten geen sprake kan zijn, toch is het gevaarlijk dat risico te loopen. Men is het eens dat aan dezen onzekeren toestand een einde gemaakt moet worden, en is doende daarvoor een verordening in het leven te roepen.

Een goede oplossing schijnt men te verwachten van een in Demerara toegepaste methode volgens de ordonnantie van 30 December 1905, bestaande in het oproepen der niet bekende eigenaren en, bij niet verschijnen binnen 12 maanden, het annexeeren van het terrein tegen taxatie, waarvan het bedrag gedurende ro jaar ter beschikking van den eventueel alsnog opdagenden eigenaar blijft. In Demerara zijn deze bedragen nooit opgeeischt.

Wil men het weder in exploitatie nemen dezer terreinen, die dikwijls tot de meest vruchtbare behooren, bevorderen, dan verdient het aanbeveling bekwamen spoed met deze verordening te maken, want zoolang men kans loopt met een onbekenden eigenaar rekening te moeten houden, zal niemand zich voor deze gronden interesseeren. Mocht een koloniale ver- 
ordening te veel tijd eischen dan geeft art. ${ }_{52}$ van het Regeeringsreglement de gelegenheid dit bij de wet te regelen.

Voor zoover wij konden nagaan, hebben de tegenwoordige eigenaren van den thans geldenden bezitvorm, allodialen eigendom en erfelijk bezit, nooit eenig nadeel ondervonden. Het is deze wijze van uitgifte van gronden, die er toe geleid heeft dat men thans sedert meer dan een eeuw verlaten plantages niet in cultuur durft brengen, wel een bewijs hoe hecht dit bezit nog is."

Mijn ondervinding is dat er heel wat meer eigenaren bekend zijn dan zoo oppervlakkig beschouwd wordt aangenomen.

Het komt mij verstandig voor alle uitgegeven gronden welke niet vóór een zekeren datum in cultuur worden genomen op een wijze dat de ernst ervan kan worden bewezen, terugkomen aan het domein op die voorwaarde dat bij weder uitgifte de concessionaris een zeker bedrag - volgens taxatie vastgesteld - aan den oorspronkelijken eigenaar moet uitbetalen.

Het is noodig dat er in die richting eens schoonschip wordt gemaakt en dat men niet al te lang overweegt enz., enz.

Over de Coronievlakte heb ik in mijn rijstartikel reeds het een en ander gezegd.

Dergelijke vlakten - al zijn zij niet zoo groot - komen ook langs Java's noordkust voor. Vanaf de kust stijgt daar het terrein langzaam om daarna in heuvel- en vervolgens bergland over te gaan.

De afstand tusschen hoogland en zee is betrekkelijk kort, waardoor in den regentijd de watermassa's dikwijls met groote kracht de vlakte overstroomden.

Voor de cultures zijn dergelijke streken pas van beteekenis geworden toen werd overgegaan tot het aanleggen van kostbare bandjirkanalen, aanvoerleidingen en kunstwerken, waardoor het watersurplus naar zee kon worden afgeleid zonder schade aan de gewassen aan te brengen, waardoor in den drogen tijd bevloeiingswater op economische wijze kan worden gedistribueerd.

Hoe geheel anders is de toestand in het Surinaamsche kustgebied en speciaal in de Coronievlakte.

In de eerste plaats is het bergland in Suriname lang niet zoo hoog als op Java, is verder de regen beter verdeeld en komen in de kolonie niet die ontzettende regenbuien voor als op Java, loopt verder het kustland veel dieper het land in.

Wat nu de Coronievlakte betreft, deze wordt in het zuiden door een terreinrug tegen overstrooming van het uit het zuiden opkomende water beschermd en door een parallel met 
de kust loopend rif kan het zeewater in het noorden de vlakte niet binnendringen.

Drains zijn daar dus slechts noodig voor afvoer van regenwater, kunnen daardoor goedkoop en snel worden gegraven en kan voor dit werk daarom gemakkelijk van graafmachines worden gebruik gemaakt, omdat het land, vooral de noordelijke streken, slechts begroeid zijn met gras en biezen.

De ontginningskosten kunnen daarom ook zeer laag zijn.

Het irrigatiestelsel voor dit langzaam naar zee afloopend terrein zal eveneens eenvoudig en weinig kostbaar behoeven te zijn.

Bij doorgraving der zuidelijkste ruggen en het aanbrengen van sluizen zal waarschijnlijk direct water kunnen worden verkregen uit de Nickerie, Wajombo en Coppename.

Graafmachines komen in verschillende grootte en constructie voor.

Een bekend type is dat van „The Buckeye Traction Ditcher Company, Findlay, Ohio, U. S. A." en wordt dit in Amerika en ook elders zeer veel gebruikt voor verschillende doeleinden.

De catalogus zegt o. m.:

„Our first machines of this type were designed especially for service in the marsh lands of Louisiana and Florida. Later, a demand was made on us to construct machines for digging through the coral formation in Florida and then to handle the heavy clay soils of Texas. .... The past year has witnessed our adoption of the bevel gear drive from the engine to the main drive shaft enz. It enables narrowing the main frame and operating the machine over areas where obstructions, such as trees and large stumps are sometimes encountered. .... In Louisiana, some of the No. 2 and No. 3. machines excavated and finished as high as $\mathrm{I}^{1} /{ }_{4}$ miles of trench perday. A No. 9 machine operating near Vancouver digging a $9 \mathrm{ft}$. top width and to a depth of $5 \mathrm{ft}$. 6 in. excavated 8.000 cubic yards in one week at a cost of $2^{1} / 2$ ct. per yard. . . . The crew required to operate such a machine is composed of two and occasionally three men, and when it is considered that this one-half mile of trench is finished without any hand labor being required, it will be self-evident that the work is done at an exceptionally reasonable cost."

Een enkele onderneming in Suriname begint dergelijke - hoewel minder krachtige - machines te gebruiken voor het aanleggen en onderhoud van trenzen.

De Heer Smits schrijft in zijn reeds vroeger aangehaald rapport :

„Het eerste werk bestaat nu in het graven van een hoofdtoevoerkanaal vanaf de Sacramentorivier of een der grootste zijrivieren tot het hoogste deel van het te bevloeien terrein. Daar de oevers van de Sacramentorivier aanmerkelijk hooger zijn dan het daarachter gelegen terrein is de ingraving in de nabijheid van de rivier vrij belangrijk. 
Voor dit graafwerk wordt gebruik gemaakt van een stoomwerktuig: de ,steam shovel".

Deze machine is in gebruik op de terreinen der Maxwell Irr. Farms Co. werd bediend door vier man, terwijl bovendien 2 man en 4 paarden noodig waren voor het gelijk maken van den opgeworpen grond en I man en 2 paarden voor het aanbrengen van water en residu.

Deze machine levert zeer goed werk en uit gemaakte aanteekeningen bleek mij, dat per man een grondverzet mogelijk was van zo kub. M."

Voor een toekomstige suikercultuur opent de Coronievlakte een zeer ruim perspectief, indien de grond werkelijk - zooals mij van planterszijde werd bevestigd - bestaat uit vruchtbare klei.

De mogelijkheid is m. i. niet uitgesloten, dat de Coppenamerivier in de toekomst een belangrijker rol zal gaan spelen dan de Surinamerivier tot heden gespeeld heeft.

De afvoer van producten der Coronievlakte zal wel in hoofdzaak naar deze rivier moeten geschieden, daar de voor Coronie liggende banken de schepen noodzaken ongeveer 2 uur uit de kust te ankeren, terwijl de Coppename, welke tot ver het binnenland in voor schepen met vrij grooten diepgang bevaarbaar is, naar mij van zeer betrouwbare zijde werd medegedeeld, een schitterend cultuurgebied doorsnijdt.

Een onderzoek naar de cultuurwaarde van dit gebied en de Coronievlakte zal tevens gepaard dienen te gaan met een opname van de oevers der benedenrivier ten einde er uittezien naar een voor moderne vestiging geschikte plaats.

\section{Spoorbaan.}

Wat het opbreken van het zuidelijk deel van de bestaande spoorbaan betreft, komt het mij nuttig voor, er hier op te wijzen, dat vóór men tot dergelijke stappen overgaat, tevoren zekerheid wordt verkregen, dat deze baan werkelijk een voor iedere onderneming beslist ongeschikt terrein doorsnijdt, omdat opbreken gemakkelijker gaat dan opbouwen.

Bij de tegenwoordige opvattingen, welke ten opzichte van Suriname onder onze leidende mannen heerschen, mag men ondoordachte dingen verwachten.

De waarde van electrischen stroom.

Ik heb reeds vroeger gewezen op het kort geleden verschenen rapport van den Amerikaanschen ingenieur Comber over de waarde der waterkrachten in Demerary voor het winnen van electrische kracht en verder voor opbouw van het land.

Vóór ik eindig, wil ik nog even het een en ander uit dit zeer belangrijke rapport aanhalen. 
Comber beschrijft de waarde dezer krachten bij den Surinaamschen buur als zeer groot; hij wil zelf stroom afstaan aan Venezuela, Brazilië en Suriname.

Hij wijst op de moeilijkheid, welke in ieder land den eersten tijd voorkomt, om het gebruik van electrischen stroom in te voeren.

„Some effort has been made by the Government to ascertain the extent of consumption of the various forms of power at present in use in the Colony, but the result so far has not been satisfactory. On 26th March, I9I9, I I I circulars of inquiry were sent to the various consumers of present forms of power. Only a few replies were received of which none were of any appreciable value."

„In this connection I recall with interest my experience some twelve or thirtheen years ago when engaged under Mr. C. H. Merz on the development of the great electric power system that now spreads over the North Eastern district of England, and that has been described by Sir Guy Calthrop, British Fuel Administrator, as a model for the world. When this great scheme was in its infancy the difficulties of gathering data and enlisting the interest and co-operation of the mechanics and managers engaged in the operation of the various mines, ship-yards, and industrial plants, seemed almost insuperable. The condition was of course natural as we were perforce obliged to deal with men having little or no knowledge of electrical work, much less of the far-reaching economic factors concerned. Despite the narrow and short-sighted attitude that had then to be faced, we find to day that the use of electric power is almost universal wherever the great distribution system of the North Eastern district of England has spread itself. Although the electrical energy there is generated by steam power, it has nevertheless been found economical to electrific railways running through the coal fields, to hoist coal from the mines electrically rather than directly by steam, and to operate virtually all the mechanical machinery of industry by electricity. This, be it remembered, in a region where coal is cheaper than anywhere else on the globe."

„On the oilfields of California it has been found cheaper to pump oil out of the ground by electric power that has been transmitted more than 100 miles than to use the oil itself as a power medium."

„In view of the facts set forth by the previous paragraphs and the further consideration that all the coal used in the Colony has to be brought from England or North America, that the existence of oil deposits in the Colony has yet to be proved, that a million dollars a year is being spent by the Colony's small though staple sugar industry on the importation of fertilizers alone that could be manufactured electrically in the Colony, the absurdity and short-sightedness of opposition or even indifference to an investigation of the Colony's water-power resources becomes manifest to an extraordinary degree.'

„From the replies received to circulars sent out by the Government, considered in conjunction with the official statistics of the production of rice, sugar, etc., and from general information gathered it would appear that the present demands would represent a maximum of 30.000 horsepower. This demand would no doubt increase rapidly as the advantages of a large supply of cheap and dependable electric power became realised. On illuminants alone the Colony spends annually some $\$ 206,000$; on coal 
nearly $\$ 5000,000$; besides wantonly burning up bagasse (ampas, uitgeperst riet) that should appear on the Colony's annual balance sheet as paper exports to the value of hundreds of thousands of dollars. At present the Colony spends more than a quarter of a million dollars a year on imported paper and over a million dollars a year on fertilizers that could and should be made in the colony."

Hij wijst verder op de groote hulp welke de dienst der waterkrachten in Amerika en Canada ondervindt van de zijde van ambtenaren en particulieren, die veel in nog weinig bekende streken verblijven en hij laat in zijn rapport de volgende zin cursief drukken: "It is impossible to emphasise too strongly the advisability, of at once commencing the recording of data concerning the flows of rivers having power possibilities."

De beschikbaarstelling van goedkoopen electrischen stroom zal de suikerindustrie in Demerary van groot nut zijn, welke thans lijdende is tengevolge van gebrek aan werkkrachten, zegt hij verder.

Ditzelfde betoogde ook ik reeds sinds 1916 ten opzichte van Suriname.

In October van dat jaar schreef ik van uit Java o.m. aan de N. Arnh. Crt.:

„De laatste jaren worden over de geheele wereld waterkrachten omgezet in electrische en zoo is het niet onmogelijk, dat de enorme in de binnenlanden van Suriname voorkomende waterkrachten omgezet in electrische het land het gemis aan voldoende werkkrachten kan vergoeden.

Waar deze stroomversnellingen en vallen gewoonlijk hooge oevers hebben, acht ik het vrijwel vaststaand, dat kunstmatig de waarde dier krachten verhoogd kan worden."

Sedert ben ik doorgegaan met te wijzen op de urgentie van een dergelijk onderzoek in Suriname, maar het bleef roepen aan een doovemans oor. De Engelschen hebben intusschen de leiding genomen en als wij niet oppassen, snelt Demerary ons nog meer vooruit en dan weder door onze eigen schuld. „Vooruitzien” mag geen specifiek Engelsche eigenschap zijn.

Onze ondervinding op het gebied der rietsuikerindustrie stelt ons instaat in komende tijden een nog grootscher werk op te bouwen dan wij gedurende de laatste drie eeuwen in verschillende tropische landen hebben opgebouwd. Suriname biedt aan een moderne rietcultuur factoren door welke het land den komenden tijd groote kapitalen tot zich zal trekken. Het heeft ondernemende mannen noodig, die tot een ernstig onderzoèk bereid zijn. 
Slot.

Van welwillende zijde wordt mij het nummer van „De Surinamer" van 28 October j.l. toegezonden, waarin een berichtje voorkomt over een plaats gehad hebbende „Tractordemonstratie":

„Vier tractors leverden prachtig werk. Men kon zien eggen, ploegen, zaaien, enz. Het was een lust om te zien hoeveel grond in korten tijd bewerkt werd en de demonstratie duidde helder aan, hoezeer de mechanische kracht een uitsparing is van levende kracht. Zoo kon men met eigen oogen aanschouwen, wat de Heer Pyttersen laatstelijk betoogde.

.... De bodem, die bewerkt werd, was een hobbelig terrein, vol gaten derhalve niet gemakkelijk te bearbeiden. Toch slaagde de proef uitmuntend. Nog werden proeven geleverd hoe boomstruiken uit den grond te verwijderen zijn. Ook deze proeven, genomen met een eenvoudig handtoestel, slaagden goed.

De demonstratie leverde het bewijs, dat landbouwmachines voor éénjarige cultures veel diensten kunnen bewijzen. Kapitaalkrachtige landbouwers zullen deze machines zeker kunnen aanschaffen, daar de onkosten spoedig gedekt zijn bij grooteren aanplant. Voor de kleine landbouwers zou het wenschelijk zijn co-operatief te werken of wel de machines te kunnen huren met deskundige bediening."

Omtrent het verwijderen van boomstronken - in Amerika o. a. die van „redwoods" - verwijs ik naar een door de wereldfirma Dupont in New-York uitgegeven boekje: „Handbook of Explosives. Instructions in the Use of Explosives for Clearing Land, Planting and Cultivating Trees, Drainage, Ditching, Subsoiling and other Purposes", een boekje dat genoemde firma (ik schreef er reeds vroeger over) gaarne gratis toezendt.

Een „Departement van Opbouw" onder leiding van een prima kracht met ruimen blik is voor Suriname ten zeerste noodig.

Een tractordemonstratie als onlangs bij Paramaribo plaats had, is zeer leerzaam, maar het mag niet anders beschouwd worden als een eerste schrede op den nieuwen grooten weg, welke voert naar, om de woorden van een Am. vakman te herhalen: ,a mammoth cane sugar industry."

Den Haag, November 1920.

\section{Naschrift.}

De Indische Mercuur van 3 Dec. j.l. neemt een bericht over uit de „Cuba Review” betreffende een „Nieuwe Machine om suikerriet te snijden." Onlangs zijn er op Cuba zeer bevredigende proeven genomen om het suikerriet op het veld af te snijden. Het is een vinding van den heer John A. Paine, werkzaam aan de Centrale Preston, eigendom van de United Fruit Comp. De ma- 
chine is een tractor met een gewicht van 5 tot 6 ton en wordt voortbewogen door een benzinemotor.

Volgens de uitvinder bedraagt de capaciteit 60 ton (ong. 900 Pic.) riet per uur. Tanden grijpen het riet, ontbladeren het en het wordt daarna automatisch op karretjes geladen, welke achter de machine aanslepen.

Aangenomen werd dat bij een hoeveelheid van 3 à 4 ton riet per dag per man met de hand gesneden, het gebruik van de machine zeer voordeelig is. De praktijk zal ten slotte moeten uitmaken in hoeverre deze berichten juist zijn.

Verder vestig ik nog even de aandacht op een berichtje in de N. Crt. van 16 Jan. 1921, over het gebruik van explosief astralit en cahalit - bij het verwijderen van boomstompen op het groote landgoed Verwolde te Laren. Twee mannen kunnen op die manier 80 zware boomstompen per dag verwijderen. De patronen kosten 16 cent per stuk, waarbij dan komen de kosten voor lontsnoer en slaghoedjes. 